\title{
Techniques for Micropropagation of Olive (Olea europaea L.): A Systematic Review
}

\author{
Inam U1 Haq ${ }^{1 *}$,Humara Umar ${ }^{2}$, Naeem Akhtar ${ }^{3}$, Muhammad Azhar Iqbal ${ }^{2}$ and Muhammad Ijaz ${ }^{1}$
}

${ }^{1}$ Barani Agricultural Research Institute (BARI), Chakwal 48800, Pakistan; ${ }^{2}$ Centre of Excellence for Olive Research and Training at BARI Chakwal, Chakwal 48800, Pakistan; ${ }^{3}$ Pakistan Oilseed Development Board (PODB), Islamabad 44000, Pakistan.

\begin{abstract}
Micropropagation is one of the most significant applications of biotechnology in the field of horticulture. This technique is used for proliferation of olive (Olea europaea L.) tree which is globally cultivated for centuries and its value added products are consumed worldwide. The traditional propagation techniques of olive are uneconomical with wastage of time while micropropagation of olive may expedite the development of important characteristics like biotic and abiotic resistance with high yield and premium quality olive oil. However, the commercial micropropagation of olive trees is currently not enough because of production cost and globally; it is mostly used for research and development on various aspects of olives. In this review, efforts are made to document the different techniques for successful initiation of olive micropropagation techniques because presently in Pakistan this technique is used at very limited research and development scale besides having basic infrastructure and necessary facilities. Therefore, authors planned to document different critical stages of olive micropropagation like; media preparation, culture establishment, shoot and root proliferation and acclimatization which would be applied for micropropagation of olives at Barani Agricultural Research Institute (BARI), Chakwal. Resultantly, olive expansion through micropropagation can be predicted in near future for sustainability of olive sector in Pakistan.

Received | September 08, 2020; Accepted | November 24, 2020; Published | March 04, 2021

*Correspondence | Inam U1 Haq, Barani Agricultural Research Institute (BARI), Chakwal 48800, Pakistan; Email: inamulhaq601@gmail.com Citation | Haq, I.U., H. Umar, N. Akhtar, M.A. Iqbal and M. Ijaz. 2021. Techniques for micropropagation of olive (Olea europaea L.): A systematic review. Pakistan Journal of Agricultural Research, 34(1): 184-192.

DOI | http://dx.doi.org/10.17582/journal.pjar/2021/34.1.184.192

Keywords | Biotechnology, Critical stages of micropropagation, Olive Research and Development, Proliferation, BARI Chakwal
\end{abstract}

\section{Introduction}

$\mathrm{M}$ icropropagation is meant for the proliferation of different plant parts under controlled and intensive environment at mass scale along with production of virus free saplings (Boustany et al., 2019). Generally, it has been used in different fields of agriculture like horticulture, forestry and plant breeding and genetics (Oseni et al., 2018). This method had been used in olive non-conventional propagation and showed a greater advantage over the traditional propagation methods. This technique is used for the production of high quality plants of olea europaea L. (Bayraktar et al., 2020).
During in vitro propagation; small pieces of mother plants/ tissues (explants) are used as a source for production of a huge amount of plants round the year. These explants have ability to develop millions of clone rapidly under less space and aseptic conditions as compared to conventional methods (Idowu et al., 2009). This method also reduces storage space limitations for maintaining a large number of explants in an aseptic environment. Olive in-vitro propagation technique is used for mass production of high quality plants during the shortest possible time. Gonzales et al., 2010 stated that this technique ensures the production of virus free plants. Matmati et. al., (2020) confirmed that micropropagation ensures the 
production of olive plants with high agronomic and phyto-sanitary qualities.

Olive (Olea europaea L.) is a member of Oleaceae family and among important fruit crops that originated in the Mediterranean region and whose products are used by people globally. The farming of olive trees has expanded from Mediterranean basin to various regions of North, South and Central Asia, South America and Australia (Afridi et al., 2015). Currently, olive is commercially growing in various parts of the world (Breton et al., 2008) and its commercial cultivation has also been started in Pakistan during past decade.

Currently, 10 million hectares of land is under olive farming worldwide. European Union is the largest producer of olives and its products having a share of $75 \%$ of world's olive production (FAO, 2020). While in Punjab; Pakistan, 4046 hectare area of Pothwar region is under olive cultivation. The main varieties grown in this region are BARI Zaitoon-1, BARI Zaitoon-2, Arbequina, Koroneiki, Gemlik and Pendolino etc. Resultantly, the demand for olive saplings is increasing during recent past. Approximately 70\% olive nursery plants produced in Mediterranean countries (Cimato, 1999) and 100\% in Pakistan are propagated through softwood, semi-hard and hardwood cuttings under mist unit of green house. Although, these techniques guarantees inherited characters; are unable to produce hard to root olive varieties because chances of success are fewer and the demand for disease free high quality plants always there (Martelli et al., 2001). These conventional methods are time consuming, laborious, have limited efficiency (Fabbri et al., 2004) and are affected by environmental factors, genetic diversity of cultivars, nutrition applied and hygienic status of the mother plants. Moreover, main drawback of these conventional methods exist, because of their weather dependency and large space requirements for extensive propagation of nursery plants.

These bottlenecks allow olive in-vitro propagation for asexual proliferation that may assume agood alternative and possible solution for propagation of olive cultivars, by minimizing and even restraining some of these constraints (Rugini and Caricato, 1995). Leva, 2011 explained that olive plants produced by in vitro method do not require "quarantine" procedure during introduction of exotic plant material. Plants produced by intensive propagation i.e. in vitro propagation have superior traits as compared with plants produced by extensive propagation i.e. conventional methods through cuttings and air layering etc. (Thorpe, 2007).

Olive in vitro propagation has many different stages namely preparation of nutrient media, selection of explants and its sterilization, inoculation, root induction and acclimatization etc. These stages are applied generally across the world and are briefly described below;

\section{Nutrient medium}

Nutrient medium used for micropropagation has all the essential nutrient elements which are inevitable for optimum growth and development of saplings. It comprises of major elements, minor elements, vitamins, organic compounds, plant growth regulators, carbon source and other gelling agents. Murashige and Skoog medium (MS medium) is most commonly used for micropropagation of many plant species. The $\mathrm{pH}$ of the medium is very critical which affects both the growing saplings as well as plant growth regulators. It is adjusted between 5.4 to 5.8. The optimum growth and development of plant cells and tissues in culture medium is directly affected by the type of plant growth regulators. The most commonly used plant growth regulators are; auxins, cytokinins and gibberellins. The higher concentration of auxins in culture medium promotes root formation while cytokinins higher concentration promotes shoot proliferation (Oseni et al., 2018).

\section{Explant material}

Selection of healthy explants is the foremost step of in vitro propagation. Before collection of explants, a fungicide spray is applied to the mother plants. The smaller explants such as shoot tip culture lead to the establishment stage of micropropagation which are free from viruses among most plant species (Hassan and Zayed, 2018). These explant received from auxiliary buds of uninodal explants taken from selected mother plants (Michelia and Da Silva, 2020).

\section{Explant sterilization}

Surface sterilization of explants is carried out through; washing under running tap water for an hour and rinsed with distilled water 2-3 times; immersion in fungicide and $70 \%$ ethanol for some time followed by multiple washing in double distilled water and $0.1 \%(\mathrm{w} / \mathrm{v})$ mercuric chloride solution with 03 drops of tween twenty on 0.5 liter distilled water for a few 
minutes followed by multiple washing in sterilized distilled water. Both ends of explants are cut off and transferred in culture vessels containing semi-solid medium.

\section{Inoculation}

After surface sterilization, the explants are inoculated in culture vessels/ containers and this activity is performed under asepsis environment. At this stage micro-cuttings are shifted on to sterilized MS media for shoot proliferation. Increased shoot proliferation of olive obtained with increasing BAP concentration up to $2 \mathrm{mg} \mathrm{L}^{-1}$ in the culture medium (Hassan and Zayed, 2018).

\section{Establishment of micro-cuttings in growth chamber}

After inoculation, the culture vessels are shifted to growth chamber for initiation of proliferation stage under photoperiod of 16 hour having optimum temperature $\left(25 \pm 3^{\circ} \mathrm{C}\right)$, relative humidity (60 to $\left.80 \%\right)$ and controlled light (1500-2000 lux) respectively. The microcuttings are kept under observation on daily basis for data recording including symptoms of any infection or contamination. The healthy microcuttings are sub-cultured on to fresh media after one month.

\section{Root induction}

Generally, rooting is induced on MS or Olive media by minimizing the concentration of major nutrient elements to half strength. For olive root induction, IBA and NAA are well known auxins. IBA is able to induce earlier rhizogenesis (Briccoli et al., 1999). Bartolini et al., 1990 developed a method for root initiation that comprises of dipping the microshoot's base into potassium salt of IBA. MS medium containing $2 \mathrm{mg} \mathrm{L}^{-1} \mathrm{IBA}$ is essential for obtaining good rooting during micropropagation. Moreover, the culture media are provided with darkening agents

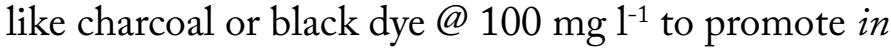
vitro rooting of explants.

\section{Acclimatization}

Acclimatization is the final stage of olive in vitro propagation; in which abrupt change in environmental conditions occur from intensive cultivation to extensive cultivation of newly developed saplings. It could be accomplished by shifting of culture plants from in vitro to ex vitro under conventional propagation structures having mist system as developed by Roussos and Pontikis, 2002. In which plants removed from the sterile medium are washed and shifted into agriculture media having equal parts of sand: peatmoss (1:1). These transplanted saplings then maintained under intermittent mist.

Keeping in view all the aforementioned factors, this review was formulated to gather different standard protocols for successful in vitro propagation of olive under autotrophic conditions.

\section{Review of literature}

In vitro propagation provides an opportunity for those horticultural fruit crops which have poor proliferation rate by conventional techniques together-with proliferation of disease free high quality clonal plants (Cancado et al.,2013). In vitro propagation methods of olive resulted in the production of genetically identical clones with superior and improved characteristics (Saghir, et al., 2005). If explants would be collected from large bearing olive plants then many constraints should be faced during intensive propagation of olive like; significant oxidation of explants cells, difficulties during surface sterilization of explants and the arduousness during initial proliferation stage with few hardy olive varieties.

\section{Establishment of aseptic culture}

Rostami and Shahsavar, 2012 reported that aseptic cultures of olive explants can be established by placing them in dark conditions. The additional treatment of antioxidants and activated charcoal remained most effective in controlling phenols and browning as well as submerging the explants in water for periods of time achieved the desirable results. Submersing the explants in water prevents phenolic compounds accumulation due to delusion of phenolic compound and or their precursors in the explants (Rugini, 1984). Roussos and Pontikis (2001) observed that antioxidants work as anti-phenolic and anti-browning agent. During in vitro propagation, establishment of aseptic culture is the most critical factor especially in evergreen perennial plants. This is time consuming and expensive. Rostami and Shahsavar, 2009 conducted a study in which approximately $95 \%$ of the node explants remained aseptic by adding $4 \mathrm{mg} \mathrm{L} \mathrm{L}^{-1}$ nano silver particles to proliferation medium. These particles discharge silver ions, which can break down the membrane structures of microorganisms (Dibrov et al., 2002). Rostami and Shahsavar, 2012 studied that submersion of micro-cuttings in ascorbic and citric acid for 30 minutes as antioxidants controls the phenolic compounds. After injury, many woody 
plants exude anti growth agents which impede the establishment of in vitro cultures. Roussos and Pontikis, 2001 stated that these anti-growth agents are lethal for olive clones. Hassan and Zayed, 2018 reported that surface sterilization of explants obtained by use of Clorox and tween 20 solution. Citric acid and ascorbic acid at $150 \mathrm{mg}$ per lit. and $100 \mathrm{mg}$ per lit. are best treatment for controlling phenol exudation. The similar findings were reported by Mangal et al., 2014. Ahmed et al., 2016 stated that mancozeb prevented fungal contamination up to $90 \%$ and $20 \%$ chlorox maximize sterilization. These findings are in line with Afridi et al., 2015. Zacchini and Agazio, 2004 used Mercuric chloride and sodium hypochloride to overcome this problem (Table 1).

\section{Table 1:}

\section{Chemicals/com- Action pounds to establish aseptic culture}

Anti-oxidants

Submersion of micro-cuttings in ascorbic $\left(100 \mathrm{mg} \mathrm{l}^{-1}\right)$ and citric acid $\left(150 \mathrm{mg}^{-1}\right)$ for 30 minutes controls the phenolic compounds

Activated charcoal Prevents the browning by creating dark environment

Nano-silver parti- $\quad 95 \%$ of the nodal explants remained cles aseptic by adding $4 \mathrm{mg} \mathrm{L} \mathrm{L}^{-1}$ nano silver particles to proliferation medium

Chlorox and tween Surface sterilization of explants obtained 20 by use of Clorox and 03 drops of tween 20 solution

Mancozeb

Mercuric chloride

did comparison among woody plant medium, Olive medium and Murashig and Skoog. Their findings support the olive medium for obtaining high quality olive clones during in vitro studies. Many scientists across the globe acknowledged the Rugini olive media having essential macro and micro-elements inevitable for in vitro proliferation (Zuccherelli and Zuccherelli, 2002; Rkhis et al., 2011) (Table 2).

Table 2:

\section{Culture medium}

Rugini olive Maximum shoots produced in the presence media of Zeatin

Murashig and skoog

Olive Media

Most commonly used for micropropagation of many plant species

in vitro studies

Driver-kuniyuki Maximum shoots and nodes obtained in walnut (DKW) Iranian olive varieties

\section{Shoot proliferation}

During olive in vitro propagation, shoot proliferation is a major difficulty encountered during culture establishment. Shoot multiplication under in vitro condition is largely depends on plant genotype and cytokinin concentration (Radmann et al., 2011) so cytokinin concentration in medium must be optimized in order to get effective shoot proliferation (Micheli et al., 2010). Rugini, 1984 documented that among zeatin; cytokinin is the most desirable plant growth regulator for rapid proliferation of olive explants because it does not easily degrade or breakdown hence remain in a nutrient media. Saghir et al., 2005 supported the earlier research findings on zeatin use for intensive proliferation of olive but also pointed out that its high cost could be an obstacle for commercial employment of this useful tool. Due to this fact, olive tissue culture practices are not applied in commercial nursery sector. This failure is correlated with hard to shoot and root ability of olive mature plants (Lambardi and Rugini, 2003; Rostami and Shahsavar, 2012). To resolve this important issue; many scientists in the world developed different technologies during past two decades (Gyves et al., 2008; Ali et al., 2009).

\section{Possible replacement of zeatin for shoot proliferation}

Peixe et al., 2007 conducted a study in which they proved the successful replacement of zeatin with natural source of growth regulator i.e. coconut water. They concluded that $50 \mathrm{ml} \mathrm{L}^{-1}$ coconut water resulted in the presence of Zeatin. Moradnezhad et al., 2017 
in maximum shooting percentage on monthly basis. Micheli et al., 2018 proved with experimentation that neem oil could also be used for successful intensive proliferation. Moreover, it is a naturally occurring compound and very economical. Antonopoulou et al., 2018 studied the use of Dikegulac on olive intensive proliferation and found that it is not phytotoxic and much cheaper than zeatin. Sweeta et al., 2019 determined the effect of combination of coconut water, cytokinin and light intensity for enhanced direct in vitro organogenesis of olives (Table 3).

\section{Table 3:}

\section{Compounds Mode of action}

Coconut oil $50 \mathrm{ml} \mathrm{L}^{-1}$ coconut water and $2.22 \mu \mathrm{M} \mathrm{BAP}$ in olive medium resulted in maximum shooting percentage

Neem oil Addition of $0.1 \mathrm{ml} \mathrm{L}^{-1}$ of neem oil to the olive medium resulted in shoot regeneration improvement

Dikegulac Rugini olive medium supplemented with dikegulac at $100.5 \mu \mathrm{M}$ produced desireabl shooting

\section{Alternate methods of shoot proliferation}

In vitro culturing requires enough monetary inputs that should be rationalized and it is essentially needed to use this technique more efficiently to achieve economic benefits. The researchers developed a Temporary Immersion System (TIS) for olive intense proliferation which is now available (Benelli and Carlo, 2018). Similarly, Lambardi et al., 2006 used the RITA ${ }^{\circledast}$ system for shoot proliferation of olive and achieved good results in comparison with use of zeatin. Leva, 2011 developed an ex vitro rooting method for olive micro cuttings and found that it is a viable solution for lowering the production cost and time required for propagation of intensively grown olive plants (Table 4).

\section{Table 4:}

\section{Methods}

Temporary immersion system (TIS) RITA $^{\circ}$

\section{Shoot proliferation}

Olive shoots propagated through immersion frequency of 8 minutes after every 16 hour and additional ventilation showed good adaptability and better growth.

$30 \%$ shoot proliferation achieved for olive shoots with immersion frequency under this system application for root induction in woody plants is being used since long and its influence on root primordia induction is well understood (Frett et al., 2001). Among auxins, IBA and NAA are most commonly used for root induction and proliferation. However, due to many positive attributes of IBA it is preferable auxin than others like its non-toxic behavior and high stability factor (Hartmann et al., 2007). Saghir et al., 2005 reported that IBA produced maximum roots in dark culture conditions (Table 5).

\section{Table 5:}

\section{Rootinghormone Concentration}

IBA in olive medium $3 \mathrm{~g} \mathrm{~L}^{-1} \mathrm{IBA}$ resulted upto85\% rooting IBA in MS medium $2 \mathrm{mg} \mathrm{L}^{-1}$ IBA essential for rooting IBA in modified $\quad 1.25 \mathrm{mg} \mathrm{L}^{-1}$ showed fairly alluring olive medium response towards rooting

\section{Alternate methods to enhance in vitro rooting}

Druart, 1997 reported that higher dose of auxins in culture media could be a limiting factor for poor in vitro rooting. Olive is a hard to root plant and its rooting ability could be altered by using different types of rooting hormones. Mencuccini, 1995 documented that intensive root proliferation could be achieved by keeping the cultures in dark environment or by incorporation of chemicals into media which have darkening effects. Significant results were achieved by Rugini et al., 1993 when they painted vessel base and used polycarbonate granules on media. Mencuccini, 2003 and Haq et al., 2009 achieved maximum rooting by using darkening agent during root proliferation stage. Rhizogenesis is the most important step for successful intensive propagation of olives because it is directly correlated with acclimatization of the young saplings in ex vitro environment (Rocha et al., 2008).

\section{Acclimatization}

During acclimatization abrupt change observed in growth conditions of intensively grown clonal plants due to shifting from intensive to extensive growth environment. Resultantly, these clones faced biotic and abiotic stress and to protect them from possible stress their appropriate transplanting must be ensured. For their transplanting different agriculture media like sand, peat moss and perlite etc. are used (Hassan and Zayed, 2018) and these intensively grown saplings must be kept under glass house infrastructure for a period of one year hardening to ensure high humidity and low temperature before 
shifting into in vivo environmental conditions. Mencuccini, 1995 reported that a mixture of potting medium including vermiculite, sand and peatmoss in equal proportions produced best results for hardening of olive saplings (Table 6).

\section{Table 6:}

Conditions In vitro grown saplings kept under glass house for acclima- conditions to ensure high humidity (80-90\%) tization and low temperature $\left( \pm 23^{\circ} \mathrm{C}\right)$ before open field transplantation

\section{Conclusions and Recommendations}

The aim of this review was to combine the study of olive in vitro propagation performed by different scientists worldwide. Although many protocols are documented for the intensive propagation of olive; out of these, most competitive and economical methods would be applied for initiation of in vitro research studies on olives at Barani Agricultural Research Institute, Chakwal. Therefore, the findings of this publication would be helpful in future for developing certain protocols for available olive germplasm in Pakistan which could be used in public sector for commercial propagation of disease free olive plants. Consequently, the expansion of olive in vitro propagation can be predicted in near future in Pakistan.

\section{Novelty Statement}

Olive is a hard to root woody plant specie which is conventionally propagated vegetatively through cuttings and air layering but the overall success rate of nursery plants varies from 25-30 percent only and most of the plants remained contaminated with different pathogens. However, the olive plants produce through micropropagation are disease / virus free and can be propagated round the year under controlled conditions with maximum survival rate. Therefore, micropropagation should be explored for sustainability of Pakistani olive sector.

\section{Author's Contribution}

Inam U1 Haq: Conceived the idea, wrote abstract, introduction and methodology.

Humara Umar: Technical input at every step, wrote results, discussion and conclusion.

Naeem Akhtar: Data collection, analysis and review of literature.
Dr. Muhammad Azhar Iqbal: Data collection and references.

Dr. Muhammad Ijaz: Overall management of the article.

\section{Conflict of interest}

The authors have declared no conflict of interest.

\section{References}

Afridi, M.I., N. Ali, K.I. Shinwari, M.A. Hassan, A.A. Butt, A. Shah, S. Salman and A. Muhammad. 2015. Optimization of aseptic conditions for micropropagation of olive (Olea europaea L.) cultivar Uslu. J. Biomol. Sci., 3(1): 35-43.

Ahmed, N., N. Khan, F. Ali, K.U. Rahman, S. Bahadar, M.I. Khan, S.U. Jan, R. Bahadur, Z. Rehman, R. Zardad, M. Hubab, S. Zahoor, A. Hayat and M. Anwar. 2016. Comparison of Different Parameters for the in-vitro Propagation of Various Cultivars of Olive (Olea europaea L.). Int. J. Basic Med. Sci. Pharm., 6(1): 4-8.

Ali, A., T. Ahmad, N.A. Abbasi and I.A. Hafiz. 2009. Effect of different media and growth regulators on in vitro shoot proliferation of olive cultivar Moraiolo. Pak. J. Bot., 41: 783-795.

Antonopoulou, C., K. Dimassi, I. Therios and C. Chatzissavvidis. 2018. Dose dikegulac affect in vitro shoot proliferation and hyperhydricity incidence in olive explants? Hortic. Sci. (Prague)., 45: 125-130. https://doi. org/10.17221/212/2016-HORTSCI

Bartolini G., A.R. Leva and A. Benelli. 1990. Advances in in vitro culture of the olive: propagation of cv. Maurino. Acta. Hortic., 286: 41-44. https://doi.org/10.17660/ ActaHortic.1990.286.3

Bayraktar, M., S.H. Smedley, S. Unal, N. Varol and A. Gurel. 2020. Micropropagation and prevention of hyperhydricity in olive (Olea europaea L.) cultivar Gemlik. South Afr. J. Bot., 128: 264-273. https://doi.org/10.1016/j. sajb.2019.11.022

Benelli, C. and A.D. Carlo. 2018. In vitro multiplication and growth improvement of Olea europaea L. cv. Canino with temporary immersion system (Plantform ${ }^{\mathrm{TM}}$ ). Biotechnology, 8: 317. https://doi.org/10.1007/s13205-018-1346-4

Boustany, N., R.E. Khoury, G. Hassoun, N. Sakr 
and G.M. Scarpa. 2019. Micropropagation of the millennium olive trees (Olea europaea L.) in bshaaleh Lebanon. Int. J. Curr. Res., 11(04): 2751-2759.

Breton, C., J. Guerin, C. Ducatillion, F. Madaild, C. Kulle and A. Berville. 2008. Taming the wild and 'wilding' the tame: Tree breeding and dispersal in Australia and the Mediterranean, Plant Sci., 175: 197-205. https://doi.org/10.1016/j. plantsci.2008.05.013

Briccoli, B.C., A. Fodale, R. Mule and T. Trombino. 1999. Trials to increase in vitro rooting of Olea europaea L. cuttings. Acta. Hortic., 474: 91-94. https://doi.org/10.17660/ ActaHortic.1999.474.15

Cancado, G.M.A.C., T.A. Setotaw and J.L. Ferreira. 2013. Applications of biotechnology in olive. Afr. J. Biotech., 12(8): 767-779.

Cimato, A., 1999. Nursery production of olive plants. Conseil Oleicole International (ed.). In: International seminar on scientific innovations and their applications to olive farming and olive oil technology. Conseil Oleicole. Int., Madrid, pp. 1-30.

Dibrov, P., J. Dzioba, K.K.M. Gosink and C.C. Ha"se. 2002. Chemiosmotic mechanism of antimicrobial activity of $\mathrm{Ag}^{+}$in Vibrio cholera Antimic. Agen. Chemot., 46(8): 2668-2670. https://doi.org/10.1128/AAC.46.8.26682670.2002

Druart, P., 1997. Optimization of culture media components for rooting Malus domestica Borkh. $\mathrm{Cv}$ compact Spartan in vitro. Biol. Plant, 39(1): 67-77. https://doi. org/10.1023/A:1000309023415

Fabbri, A., G. Bartolini, M. Lambardi and S. Kailis. 2004. Olive propagation manual. CSIRO Publishing, Collingwood, pp. 77-95. https:// doi.org/10.1071/9780643091016

Food and Agriculture Organization of the United Nations, 2020. Available at: http://www.fao. org/land-water/databases-and-software/cropinformation/olive/en/ (Accessed:22 June 2020).

Frett, N.A.G., A.G. Gett, L.W.V. Goulart, R.R. Pasquali, R.R. Termignoni and A.G. Ferreira, 2001. Distinct effect of auxin and light on adventitious root development in Eucalyptus saligna and Eucalyptus globules. Tree Physiol., 21: 457-464. https://doi.org/10.1093/ treephys/21.7.457

George, E.F., 1993. Plant propagation by tissue culture. Part 1, the Technology, Exegetics Ltd. Edington.

Gonzales, G.R., K. Quiroz, B. Carrasco and P. Caligari. 2010. Plant tissue culture: Current status, opportunities and challenges. Cien. Inv. Agric., 37(3): 5-30. https://doi.org/10.4067/ S0718-16202010000300001

Gyves, M.D.E., F.R. Mira and R.E. Rugini. 2008. Stimulation of node and lateral shoot formation in micropropagation of olive (Olea europaea L.) by using dikegulac. Plan Cell Tiss. Org. Cult., 92: 233-238. https://doi.org/10.1007/s11240007-9314-4

Haq, I.U., T. Ahmad, I.A. Hafiz and N.A. Abbasi, 2009. Influence of microcutting sizes and IBA concentrations on in vitro Rooting of Olive cv. 'Dolce Agogia'. Pak. J. Bot., 41(3): 1213-1222.

Hartmann, H.T., D.E. Kester, Jr. F.T. Davies and R.L. Geneve. 2007. Plant Hormones. $7^{\text {th }}$ Edition, In: Plant Propagation: Principles and practices. Prentice-Hall, New Delhi, pp. 292320.

Hassan, S.A.M. and N.S. Zayed. 2018. Factor controlling micro propagation of fruit trees: A Review. Sci. Int., 6: 1-10. https://doi. org/10.17311/sciintl.2018.1.10

Idowu,A.P.E.,D.O. Ibitoye and O.T.Ademoyegun. 2009. Tissue culture as plant production technique for plant horticultural crop. Afr. J. Biotech., 8(16): 3782-3788.

Lambardi, M. and E. Rugini. 2003. Micropropagation of olive (Olea europaea L.). In: S.M. Jain and K. Ishii (eds.). Micropropagation of woody trees and fruits. Kluwer Academic Publishers, Dordrecht. The Netherlands. pp. 1-5. https:// doi.org/10.1007/978-94-010-0125-0_21

Lambardi, M., C. Benelli, Y.O. Tokatli, E.A. Ozudogru and F. Gumusel. 2006. A novel approach to olive micropropagation: The temporary immersion system. MarsalaMazaradel Vallo, Italy. Proc. $2^{\text {nd }}$ Int. Semin. Olive Bioteq., 1: 319-326.

Leva, A.1., 2011. Innovative protocol for "ex vitro rooting" on olive micropropagation. Cent. Eur. J. Biol., 6(3): 352-358. https://doi.org/10.2478/ s11535-011-0010-3

Mangal, M., D. Sharma, M. Sharma and S. Kumar. 2014. In vitro regeneration in olive (Olea europaea L.) cv, 'Frantoio' from nodal segments. Indian J. Exp. Biol., 52: 912-916.

Martelli, G.P., E. Zamboni, G. Zuccherelli and M. 
Barba. 2001. Lorganizzazione di un moderno vivaismo olivicolo alla base della production di piante certificate. Frutticoltura, 5: 11-24.

Matmati,M.,H.R.Khouja andM.B.Mimoun.2020. Characterization of olive plants (Olea europaea L.) obtained with micropropagation and cuttings. Acta. Hortic., 1285: 131-138. https:// doi.org/10.17660/ActaHortic.2020.1285.21

Mencuccini, M., 1995. Micropropagazione e miglioramento genetic in vitro dell' Olivo: Stato dell'arte e prospettive future. Frutticoltura, 12: 73-82.

Mencuccini, M., 2003. Effect of medium darkening on the in vitro rooting capability and rooting seasonality of olive (Olea europaea L.) cultivars. Sci. Hortic., 97: 129-139. https://doi. org/10.1016/S0304-4238(02)00130-9

Micheli,M.,A.Standardi,A.W.El-Behi,D.Zakhour and M. Yasin. 2010. In vitro proliferation of olive ('Dolce Agogia' and Moraiolo'): Effect of different cytokinins. Proc. XI ${ }^{\text {th }}$ IS on plant bioregulators in fruit production Ed.: G. Costa. Acta. Hort., 884, ISHS.587-590. https://doi. org/10.17660/ActaHortic.2010.884.76

Micheli, M., D.F.D. Silva, D. Farinelli, G. Agate, R. Pio and F. Famiani. 2018. Neem oil used as a "Complex Mixture" to improve in vitro shoot proliferation in olive. Hortic. Sci., 53(4): 531-534. https://doi.org/10.21273/ HORTSCI12731-17

Micheli, M. and D.F. da Silva. 2020. Biotechnological tools for quality olive growing. JOJ Wild Biodivers, 2(1): 555-583.

Moradnezhad, M., R. Hosseini, M.M. Zarrabi and F. Ghane. 2017. A new approach for olive (Arbequina cv.) Micropropagation: Effect of dikegulac, light and carbon source. Int.J. Hortic. Sci. Technol., 4(1): 79-87.

Oseni, O.M., V. Pande and T.K. Nailwal. 2018. A review on plant tissue culture, a technique for propagation and conservation of endangered plant species. Int. J. Curr. Microbiol. App. Sci., 7(07): 3778-3786. https://doi.org/10.20546/ ijcmas.2018.707.438

Peixe, A., A. Raposo, R. Lourenco, H. Cardoso and E. Macedo. 2007. Coconut water and BAP successfully replaced zeatin in olive (Olea europaea L.) micropropagation. Sci. Hortic., 113: 1-7. https://doi.org/10.1016/j. scienta.2007.01.011

Peyvandi, M., F. Farahani, Z. Noormohamadi, O.
Banihashemi, M. Hosseini, Mazinani and S. Ataee. 2009. Mass production of Olea europaea L. (Cv. Rowghani) through micropropagation. Gen. Appl. Plant Physiol., 35(1-2): 35-43.

Plantigen Himedia. Available at: www.himedialabs. com (Accessed: 22 June 2020).

Radmann, E.B., V.J. Bianchi, J.C. Fachinello, L.V. Ferreira and R.P.D. Oliveira. 2011. In vitro multiplication of 'flordaguard' rootstock: Cytokinin source and concentration effects, explants orientation and period of permanence in the culture medium. Braz. Arch. Boil. Technol., 54(1): 25-34. https://doi.org/10.1590/S151689132011000100004

Rkhis, A.C., M. Maalej, N. Drira and A. Standardi. 2010. Micropropagation of olive tree Olea europaea L. 'Oueslati'. Turk J. Agric., 35(2011): 403-412.

Rkhis, C.A., A. Trigui and N. Drira. 2011. Micropropagation of Tunisian cultivars of olive tree: Preliminary results. Acta Hortic., 474: 79.

Rocha, M.A.C., M.A.P.C. Costa, S.A. Silva, C.A.S. Ledo, M.J.S. Moreira and L.P. Bastos. 2008. In vitro rooting and acclimatization of genotypes of jenipapeiro (Genipa Americana L.). Rev. Bras. Frutic., 30(3): 769-774. https:// doi.org/10.1590/S0100-29452008000300035

Rostami, A.A. and A.R. Shahsavar. 2012. In vitro micropropagation of olive (Olea europaea L.) 'Mission' by nodal segments. J. Biol. Environ. Sci., 6(17): 155-159.

Rostami, A.A. and A. Shahsavar. 2009. Nano-silver particles eliminate the in vitro contaminations of olive 'mission' explants. Asian J. Plant Sci., 8: 505-509. https://doi.org/10.3923/ ajps.2009.505.509

Roussos, P.A. and C.A. Pontikis. 2001. Phenolic compounds in olive explants and their contribution to browning during establishment stage invitro. Gartenbauwissenschaft, 66(6): 298-303.

Roussos, P.A. and C.A. Pontikis. 2002. In vitro propagation of olive (Olea europaea L.) cv. Koroneiki. Plant Growth Regulat., 37: 295-304. https://doi.org/10.1023/A:1020824330589

Rugini, E. and G. Caricato. 1995. Somatic embryogenesis and plant recovery from mature tissues of olive cultivar (Olea europaea-L.) 'Canino' and 'Moraiolo'. Plant Cell Rep., 14(4): 257-260.https://doi.org/10.1007/BF00233645 Rugini, E., 1984. In vitro propagation of some 
olive (Olea europaea L.) cultivars with different rootability and medium development using analytical data from developing shoot and embryos. Sci. Hortic., 24: 123-134. https://doi. org/10.1016/0304-4238(84)90143-2

Rugini, E., A.Jacoboni and M. Luppino. 1993. Role of basal darkening and exogenous putrescine treatment on invitro rooting and on-endogenous polyamine changes in difficult-to-root woody species. Sci. Hortic., 53: 63-72. https://doi. org/10.1016/0304-4238(93)90138-G

Rugini, E., G.P. Pesce and P.L. Sampinato. 1999. New perspective for biotechnologies in olive breeding: morphogenesis, in vitro selection and gene transformation. Acta. Hortic. (ISHS), 474: 107-110. https://doi.org/10.17660/ ActaHortic.1999.474.18

Saghir, S., P.H. Chatelet, N. Ouazzani, F. Dosba and I. Belkoura. 2005. Micropropagation of eight Moroccan and French olive cultivars. Hortic. Sci., 40(1): 193-196. https://doi.org/10.21273/
HORTSCI.40.1.193

Sertkaya, S.G. and A. Cinar. 1999. Detection of a new medium for bud wood culture in vitro of citrus. Turk. J. Agric. For., 23: 333-340.

Sweeta, M., K. Shailesh and Y. Vala. 2019. Effects of coconut water, plant growth regulator and lightintensity on shoot bud proliferation and direct regeneration in-olives (Olea europaea L.). J. Pharm. Phytophram., 8(3): 846-850.

Thorpe, T., 2007. History of plant tissue culture. J. Mol. Micro. Biotech., 37: 169-180. https://doi. org/10.1007/s12033-007-0031-3

Zacchini, M. and M.D. Agazio. 2004. Micropropagtion of a local olive cultivar for germplasm preservation. Biol. Plant, 48(4): $\quad$ 589-592. https://doi.org/10.1023/ B:BIOP.0000047156.57328.27

Zuccherelli, G. and S. Zuccherelli. 2002. In vitro propagation of fifty olive cultivars. Acta Hortic., 586: 931. https://doi.org/10.17660/ ActaHortic.2002.586.204 